\title{
STRATEGIES AND PROCESSES IN INDIAN RAILWAYS - AN ANALYSIS
}

\author{
Mrs. Ruby Selwyn ${ }^{1}$ and Dr. N Thangavel ${ }^{2}$, \\ ${ }^{1}$ Research Scholar, Sathyabama University, Rajiv Gandhi Road, Chennai, India \\ ${ }^{2}$ Principal, Jeppiaar Institute of Management, Rajiv Gandhi Road, Chennai, India
}

\begin{abstract}
Indian Railways (IR), which was declared to be heading towards bankruptcy as per the Expert Group on Indian Railways in 2001, is today the second largest profit making Public Sector Undertaking after ONGC. The fund balance crossed Rs. 12,000 crores in 2005-06, which had reached a low of just Rs. 149 crores in 1990-2000. The total investment being planning for the eight-year time frame (2008-2015) is tentatively in the order of Rs.350,000 crores. This confidence is not only due to the rising trend of performance, but also due to the significant growth in the past hree years. These three years coincided with Mr. Lalu Prasad being at the helm of affairs of the IR, having moved into his position on 23rd May, 2004. Railway officials called this as the 'turnaround' of IR. This paper attempts a diagnosis of the 'turnaround,' beginning with the question as to whether it really was a 'turnaround'. This paper then carried out an analysis of the various determinants of the 'turnaround' related to goods, passenger and other operations. This is followed by a critical assessment of the strategies and key processes being the 'turnaround'. Finally the sustainability of the 'turnaround' is explored.
\end{abstract}

Key words: Bankruptcy, Public Sector Undertaking, Turnaround Strategy

\section{INTRODUCTION}

The Minister for Railways (MR), Mr Lalu Prasad, the Chairman and Members of the Railway Board (RB) were reviewing investments for the XI Five Year Plan in mid July 2006. The focus areas that had been put forth in the XI Plan Approach Paper were [1]: 1. Capacity augmentation, 2. Establishment of logistic parks and terminals 3. Rationalization of freight structures 4. Increased use of IT enabled services 5 . World class quality passenger amenities 6 . Public-private partnerships for building and operation of rail infrastructure 7. Design of high capacity wagons 8. Restructuring of IR to focus on core activities 9. Establishing a Rail Tariff Regulatory Authority

The total investment being planned for the eight year time frame (2007-2015) was tentatively in the order of Rs 350,000 crores. This was a significant increase from the planned Rs 60,000 crores (actual expected to cross Rs 80,000 crores) in the X Plan period of 2002-07. This confidence was a result of what the Indian Railways (IR) achieved, not only due to the rising trend of performance, but also due to the significant growth in the past four years (2004-08) [4].

The fund balances had crossed Rs 12,000 crores. These years coincided with Mr Lalu Prasad being at the helm of affairs of the IR, having moved into his position on 23rd May, 2004. Mr Lalu Prasad, in his opening remarks of the budget speech of 2006-07 on 24th February 2006 had said that he is presenting the Budget Estimates 2006-07 for the Indian Railways at a point in time when, there has been a historical turnaround in the financial situation of the Indian Railways.
Table 1. Performance of Indian Railways

\begin{tabular}{|l|l|l|l|l|l|l|l|}
\hline Particulars & \multicolumn{7}{|c|}{ Year } \\
\cline { 2 - 8 } & $2001-02$ & $2002-03$ & $2003-04$ & $2004-05$ & $2005-06$ & $2006-07$ & $2007-08$ \\
\hline Gross Traffic & 37,838 & 41,068 & 42,905 & 47,370 & 54,491 & 59,978 & 69,574 \\
Receipts & & & & & & & \\
\hline Earnings: & 24,845 & 26,505 & 27,618 & 30,778 & 36,287 & 42,456 & 43,256 \\
a. Goods & 11,196 & 12,575 & 13,298 & 14,113 & 15,126 & 44,574 & 49,312 \\
b. Passenger & 1,797 & 1,988 & 1,989 & 2,479 & 3,078 & 3,632 & 4,121 \\
c. Other & & & & & & & \\
(Coaching, & & & & & & & \\
Sundry and & & & & & & & \\
Suspense) & & & & & & & \\
\hline
\end{tabular}

IR was considered to be heading towards bankruptcy, as per the report of Expert Group on Indian Railways (also called the Rakesh Mohan Committee report), submitted in July 2001 which studied the IR for nearly two years [2]. They had stated that IR is on the verge of a financial crisis... To put it bluntly, the 'business as usual low growth' will rapidly drive IR to fatal bankruptcy, and in sixteen years, Government of India will be saddled with an additional financial liability of over Rs 61,000 crores... On a pure operating level, IR is in a terminal debt trap. The fund balance at the end of 1999-00 had reached a low of Rs 149 crores, improving to Rs 5228 crores by the end of 2003-04 and over Rs 12,000 crores by the end of 2005-06.

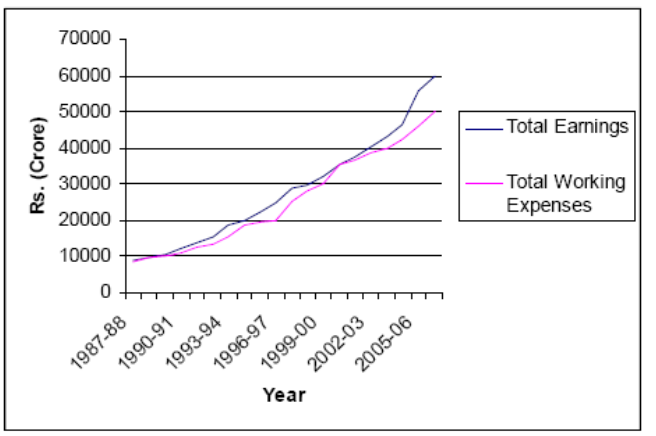

Fig. 1. Total Earnings and Total Working Expenses 


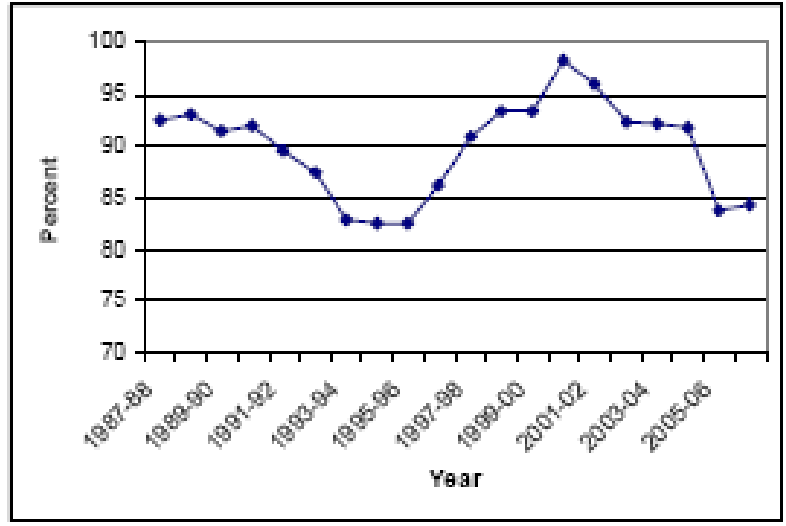

Fig. 2. Operating Ratio

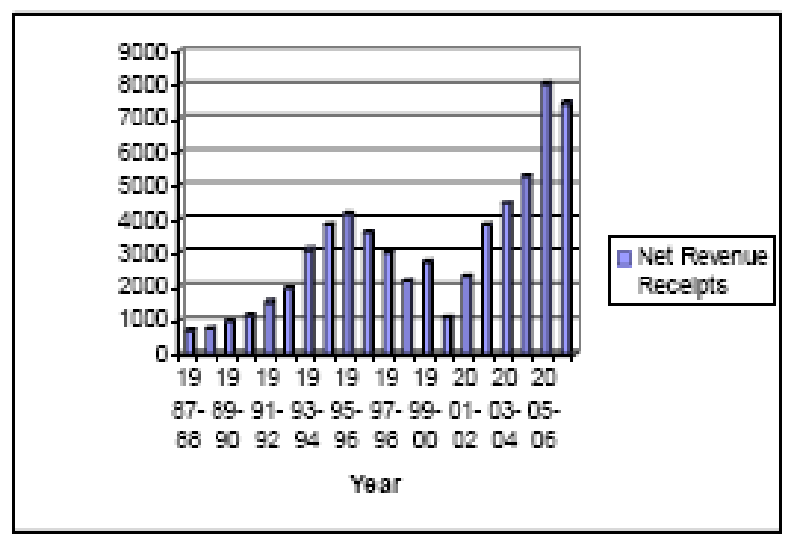

Fig. 3. Net Revenue Receipts

A 20 year perspective since 1987-88 gives a bird's eye view of the performance of $I R$, in terms of total earnings, total working expenses, operating ratio and net revenues as shown in Fig.1, Fig.2 and Fig.3 [5].

The operating ratio (ratio of total working expenses (including depreciation and pension, but exclude dividend to $\mathrm{GOI}$ ) to total earnings) and net revenues (total earnings less total working expenses, adjusted with miscellaneous transactions) had reached low levels of performance in $2000-01(98.3 \%)$ and then had consistently improved till 2005-06 (83.7\%) [10].

\section{TURNAROUND DIAGNOSTICS}

To diagnose the 'turnaround,' the first question would be whether it really was a 'turnaround.'. The total earnings in 2005-06 increased by Rs 7121 crores, a 15.0\% growth with respect to 2004-05. The total earnings in 2004-05 increased by Rs 4465 crores, a $10.4 \%$ growth with respect to 2003-04. Similar figures for the earlier years since 200102 ranged between $4.5 \%$ and $8.5 \%$ with respect to the previous year. The total working expenses plus the lease charges towards principal payments in 2005-06 increased by Rs 4431 crores, a 10.4\% rise with respect to 2004-05.
The total working expenses in 2004-05 increased by Rs 3277 crores, a 8.3\% rise with respect to 2003-04.Similar figures for the earlier years since 2001-02 ranged between $3.8 \%$ and $4.8 \%$ with respect to the previous year. As a consequence of the total earnings and total working expenses, the net revenue reached a record of Rs 8005 crores in 2005-06, following the Rs 5274 crores in 200405. This was a record increase of Rs 2731 crores, reflecting a $52 \%$ increase in net revenues. Earlier, until 2004-05, there had been a steady climb from the low of Rs 1071 crores in 2000-01. The internal generation of cash surplus including provision for depreciation and Special Railway Safety Fund (SRSF) reached an historic level of Rs.13,068 crores for 2005-06, following the Rs 7603 crores in 2004-05. The essence of the 'turnaround' was in the fact that (i) total revenues increased by a significant percentage in the last two years and (ii) the net revenues continued a robust upward trend. This justified the principles that "freight business is a play on volumes," and that "passenger business is a play on volumes and quality" which were behind various focused initiatives undertaken by the MR, and driven by the RB. Further, the initiatives were pursued in a manner that results could be obtained as quickly as possible, yet laying the foundation for continued performance improvements. An interesting aspect was that the total earnings in 2005-06 had gone up by a record Rs 3523 crores with respect to the budget estimates (BE) for the year. While this could raise questions about the budgeting process, for the year 200506 it is more of a consequence of initiatives that were put in place during the year, with results coming in the same year.

The next question would be the determinants of the 'turnaround':

2.1 Goods Earnings The increase in goods earnings for 2005-06 over 2004-05 was Rs 5509 crores, including miscellaneous earnings due to wharfage and demurrrage. Excluding the miscellaneous, the increase was Rs 5482 crores. An analysis of the commodities through which the increased goods earnings were obtained. Coal (Rs 1365 crores), other goods including raw material (iron ore, limestone and dolomite) for other than major steel plants, and other stones, sugar, salt, non bulk goods and containers (Rs 1121 crores), iron ore for exports (Rs 733 crores), cement (Rs 550 crores), raw material for steel plants (Rs 475 crores), fertilizers (Rs. 449 crores) and pig iron and finished steel (Rs 373 crores) accounted for $92 \%$ of the increase in earnings, in that order. The increase in earnings from coal and other goods were largely due to the increased loadings. The

increase in earnings from iron ore for exports was both due to increase in loading and increase in rates by change of 
classification. The increase in earnings from cement was due to increase in loading. The increase in earnings from raw material for steel plants was due to the increased loading and increase in rates by change of classification. The increase in earnings from fertilizers was due to the increased loading and higher lead. The increase in earnings from pig iron and finished steel was primarily due to higher lead.

\section{Table 2. Change in Freight Classes and Rates}

\begin{tabular}{|l|c|c|c|c|l|}
\hline Year & $\begin{array}{c}\text { No. of } \\
\text { Classes }\end{array}$ & $\begin{array}{c}\text { Highest } \\
\text { Class }\end{array}$ & $\begin{array}{c}\text { Lowest } \\
\text { Class }\end{array}$ & $\begin{array}{c}\text { Ratio between } \\
\text { the Highest and } \\
\text { Lowest Class }\end{array}$ & \multicolumn{1}{|c|}{$\begin{array}{c}\text { Reasons for Changes in } \\
\text { Freight Rates }\end{array}$} \\
\cline { 2 - 6 } $2003-04$ & 32 & 300 & 90 & 3.33 & $\begin{array}{l}\text { Marginal decrease in certain } \\
\text { commodities and minimal } \\
\text { increase in other commodities }\end{array}$ \\
\cline { 2 - 6 } $2004-05$ & 27 & 250 & 90 & 2.78 & $\begin{array}{l}\text { No changes, only } \\
\text { reclassification }\end{array}$ \\
\cline { 2 - 6 } $2005-06$ & 27 & 250 & 90 & 2.78 & $\begin{array}{l}\text { No changes, only } \\
\text { reclassification }\end{array}$ \\
\cline { 2 - 6 } $2006-07$ & 19 & 240 & 90 & 2.67 & $\begin{array}{l}\text { No changes, only } \\
\text { reclassification }\end{array}$ \\
\cline { 2 - 6 } $2007-08$ & 18 & 220 & 90 & 2.45 & $\begin{array}{l}\text { No changes, only } \\
\text { reclassification }\end{array}$ \\
\cline { 2 - 6 } & 18 & 90 & 2.45 & $\begin{array}{l}\text { No changes, only } \\
\text { reclassification }\end{array}$ \\
\hline
\end{tabular}

The above table [6] gives the change in freight classification and rates since 2002-03. It was important to note that while the public stance had been that there was no tariff increase, iron ore had been subject to tariff increases by revision of classification. A significant share of increase in earnings from iron ore for exports and raw material for steel plants would be attributable to this. Taking the case of iron ore for exports, a maximum of Rs 277 crores (current yield multiplied by the increase in traffic) out of the increase of Rs 733 crores was attributable to the increase in loading. The balance would be attributable to the tariff increase since there was no change in lead. Also, some of the extra income was attributable to (i) busy route surcharges, (ii) busy season surcharges and (iii) priority allotment of rakes for willingness to pay at two classes higher. A comparison

of the loading figures between 2005-06 and 2004-05 shows that increased loadings have been achieved in coal, other goods, raw material for steel plants, and iron ore for exports. The percentage increase with respect to 2004-05 was most significant for other goods $(25 \%)$ followed by raw material for steel plants $(19 \%)$, cement $(14 \%)$, and iron ore for exports (13\%). The increase in coal was $8 \%$. The increased axle load would account for a maximum of $14 \%$. The rest would be due to increased rake availability as a consequence of (i) improvements in wagon turnaround, especially in iron ore circuits due to the efforts towards 24 hour loading in sidings in SER and SWR, and reduced train examination and (ii) use of covered wagon rakes which would otherwise have gone empty in SWR. A whole host of schemes have been put in place to attract the freight customer, since July 2005 [3].
These include mini rakes for the small customer, volume discounts for the large customer, lean season discount scheme, long term freight incentive scheme, loyalty discount scheme, discounts for providing traffic in the empty direction, incentives at terminals like engine on load and construction of sidings, wagon investment scheme etc. An analysis of the above brings out the effect of the initiatives of (i) increased axle load (ii) reduced wagon turnaround and (iii) market oriented tariffs and schemes.

2.2 Passenger Earnings The passenger earnings in 2005-06 had gone up by Rs 1013 crores (7.2\%) over 200405 . Disaggregate data is not yet available to analyse the elements of this increase. The possible reasons for the earnings in 2005-06 being higher were due to initiatives in running 24 coach trains, deploying additional coaches in well patronised trains and even running of additional trains. These initiatives were made possible by ensuring analysis of demand based on the passenger reservation system data and requiring the field level officers to respond to it by additional supply where possible.

In the passenger segment, a reduction of one rupee was offered in the second class ordinary fare, $10 \%$ in ACII and $18 \%$ in $\mathrm{ACl}$. There had been increase in charges for cancellation, more trains being made superfast with a reduction in time and thus imposing a superfast charge, booking tickets from an origin different from the place of reservation, separation of tickets if a through a journey involved more than one train or a break of journey - thus not offering the telescopic benefits (the last charge has since been withdrawn). The tatkal scheme, targeted at the 'last minute' passenger was extended first

from one day to three days and then to five days. This offered a window of opportunity to increase earnings through differential pricing, based on the time of booking. Emphasis has been laid on what has been called 'touch and feel' initiatives to improve the service quality for the passenger. Consequent to the above initiatives, the growth in number of passengers has been $7.5 \%$ in 2005 06 over 2004-05 and 7.1\% in 2004-05 over 2003-04. The growth in the earlier three years had ranged between $2.4 \%$ to $5.4 \%$.

2.3 Other Earnings The increase in other earnings of Rs 599 crores (24.2\% over 2004-05) came through parcel, catering, advertising, dividends from the public sector units under the ministry etc. The increase of $24.2 \%$ in 2005-06 over 2004-05 followed a similar growth of $24.7 \%$ in 2004-05 over 2003-04. In the earlier years, the growth in this segment had been marginal. this source of revenue had not received as much focus as in the past two years $A$ slew of initiatives on these areas had been implemented over the past two years, making it attractive for private 
parties to take advantage of the market opportunity that IR could offer. For the parcel business, even though the leasing concept had been in place earlier, the implementation had been slow due to poor market response. This was given a thrust over the past two years. In a correspondence to the GMs in July 2005, the MR urged, "The GMs should ensure that all tender notices concerning parcel contracts are issued within 15 days and tenders are finalized within 2 months from the date of receipt of this letter." The zones were empowered to fix up leases if they could get a bid at $20 \%$ more than the previous year's earnings. Catering Catering was an essential service to IR passengers, both on the trains (mobile) and at the stations (static). Outsourcing in catering through the IRCTC was a major initiative, which received increased attention during the past two years. Like parcel, in the MR's correspondence to GMs, a sense of urgency was communicated focusing on the need to quickly finalize the catering contracts within three months of issuing the tender. Open competitive bidding, many times having to deal with pressures (including court litigation) brought by incumbents, had been a strategy to unlock the potential of this business activity. The political stature of Mr Lalu Prasad and his ability to deal with such pressures had enabled the GMs and IRCTC to move forward. Even then, at the end of the year, there were pending cases in courts. Advertising As stated by CCM, $\mathrm{NR}$, "easy processing of

innovative ideas for advertising was put in place." This enabled zonal railways to be more proactive on this front. As an example, the NR doubled its advertising income from the three major terminal stations: Delhi, New Delhi and Hazrat Nizamuddin in two years. The increase in earning from advertising had been even more significant in the $\mathrm{CR}$ and $\mathrm{WR}$, leveraging the Mumbai area. The overall IR earnings had gone up from Rs 50.2 crores in 2004-05 to Rs 78. 1 crores in 2005-06.

2.4 Overall Strategy The country's economy was growing faster than before, moving from the $4 \%$ to $6 \%$ GDP growth rates (from 1996-97 until 2002-03) to the $8.5 \%, 7.5 \%$ and $8.4 \%$ achieved in 2003-04, 2004-05 and 2005-06 respectively. This growth environment offered an opportunity for IR and had a significant impact on the turnaround. In the freight business, there was focus on higher volumes, on the premise that marginal revenues were significantly higher than marginal costs [9]. This was done with the objective of lowering the unit costs, resulting in the record surplus. The strategy for freight rates made a clean departure from the past (the nineties, when rates were increased and high value finished goods suffered a greater increase in rates than low value raw materials) by (i) freezing freight rate increases and (ii) rationalising the commodity classification to benefit the high value goods and charge more from the low rated commodities. The strategy of higher volumes was also carried through in the passenger business. The concept of revenue management, where in differential prices could be charged for differential services like tatkal and superfast were leveraged. In the other business areas of parcel, catering and advertising, the strategy of outsourcing through public private partnership and wholesaling rather than retailing was adopted. Underlying all this was the strategy of increasing asset utilisation.

2.5 Proposed Initiatives Continuing and building on the strategies adopted, the focus for the future is on capacity enhancement, reduction in unit cost, reducing transit times and having world class terminals. The MR, with inputs from the RB, has proposed various initiatives towards (i) improving the wagon productivity (ii) improving the mobility of wagons (iii) running of higher axle load trains (iv) improvements in asset liability and (v) infrastructure development for reducing transit times. Over a thirty year horizon, coal has

become the most important commodity for IR. Other commodities had reduced in significance, but have the potential for the future, especially due to growth in container traffic and other customer oriented schemes. The wagon turn around has been reducing consistently from a peak of 15.2 days in 1980-81 to just over 6 days in 2005-06. A recent initiative has been providing automatic upgrades to passengers in case of vacancy in a higher class, while there is a waiting list in a lower class and increasing the number of superfast trains. The MR has suggested a range of initiatives focused on (i) reducing passenger losses by increasing volumes by increasing the length and occupancy of trains (ii) modifying train length and composition based on passenger profile management (analysis of the passenger reservation system data to understand class wise and season wise occupancy of trains) (iii) increasing average speeds of trains (iv) providing affordable air-conditioned travel for the poor and (v) improved design of coaches. Related 'touch and feel' initiatives at stations and on board trains focused on the passenger would be stepped up, driven by the zonal GMs and executed through IRCTC.

\footnotetext{
Passenger

Earnings 0102030405060 SecondClass(M/E)SecondCla ss(Ordinary)Upper ClassSuburban1987-882006-07
} 


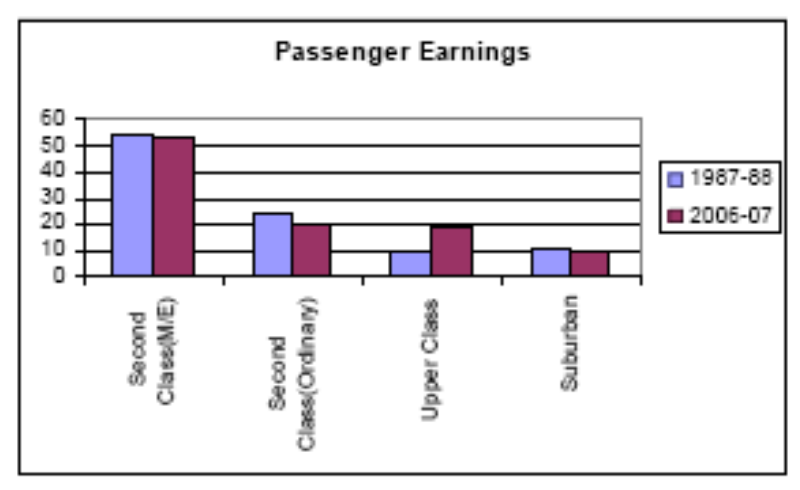

Fig. 4. Passenger Traffic Perspectives

The above figure provides a perspective on the passenger traffic trends in IR. In terms of passenger earnings, the long term trend in earnings shows a growth in second class mail/express and upper class and a reduction in second class ordinary. The trends in number of passengers are similar. This reflects an increasing focus on the long distance reserved passenger rather than the short distance unreserved passengers. Between

suburban and non-suburban, the originating passengers are more for suburban, while it is the reverse in earnings. Parcel, catering and advertising are expected to witness more aggressive efforts. Initiatives focused on the passenger being implemented by the IRCTC are (i) improving the quality of the ticketing transaction, (ii) improving value added and basic services at stations, (iii) passenger amenities on board trains, especially as an integrated service, (iv) low cost hotels and (v) leveraging tourism business. To support the above, appropriate investments are being considered. The focus has been on low cost, short gestation and high return projects. Route based throughput enhancement works are being aggressively pursued by relaxing any cap on resource availability. The other thrust areas are gauge conversions to improve the BG network flexibility, sidings and the dedicated freight corridor.

\section{CRITICAL APPRAISAL}

Processes Having attempted an appraisal of the strategies, we now critically examine some of the key processes behind them. There had been a significant increase in initiatives over the past four years. "This has brought in a confidence and up-beat attitude right through the organization". More significantly, many had been brought to a logical conclusion, through speedy execution.

\section{THE STYLE OF THE PRESENT MR}

The operationalisation of the various strategies over the past two years depended significantly on the leadership style of Mr Lalu Prasad [7]. It was a common sense based approach, showing an astute understanding of the market reality, the asset base of the $I R$ and the expertise and capability of the IR's management and systems. Consequently, he followed this up with the principles of leveraging the assets ("milk the cow fully") and empowerment and delegation. With whatever has been achieved in the 'turnaround,' Mr Lalu Prasad has demonstrated that good economics is good politics.

Non Interference: "Mr Lalu Prasad is a non-interfering, yet aware MR, who sets the goals and expects results." was stated by most of the ex-Members and the current Members of the Board. "This has given him a position of strength to build organizational alignment to see through fundamental initiatives."

Caring Attitude: Mr Lalu Prasad had a positive approach in dealing with the staff and unions. Given the financial performance of the IR, the unions wanted a doubling of the contribution to the staff welfare fund. He offered them more. When he saw that gangmen who had to walk on the stone ballast were not provided footwear as part of their equipment, he ensured the same. Running crew had to carry their own provisions for food to be cooked in the running rooms, many times at odd hours. He directed that all running rooms must outsource food and provide the same to the crew at subsidized rates. Whenever concerns were raised about downsizing of the IR, he came out with his Hindi one liner which translated to, "Downsizing may make IR thinner, but not necessarily healthier." On presenting the future, his pitch was, "regenerate competitiveness and leverage resources rather than restructure and downsize." He believed in instilling hope and excitement rather than fear and anxiety.

Image Building: Given his penchant for wit and one liners, Mr Lalu Prasad was sought after by the media. Whenever there was an opportunity to highlight an initiative or an achievement, advertisements were released [8].

\section{CRITICAL APPRAISAL}

Sustainability The final question is whether the strategies and processes are sustainable. It is important to recognize that apart from a faster growing economy, the one variable that was different in the past two years of the 'turnaround' was the political leadership. The natural corollary is that sustainability depends on the political leadership. From the perspective of IR responding to environmental changes in a fast growing economy, what is required is a framework for continued innovation. We shift our focus from just the current strategic initiatives to the process of continuing such initiatives. Towards this, the strategies and processes can be sustained if the political leadership is well intentioned and has consistency of direction. 
Political leadership does not come in through a controlled process. The need is for the professional top management to be able to respond as a commercially oriented organization with a corporate culture. Strategies and processes have to be customer centric. The current structure of the organization lends itself primarily to supply driven strategies, where at best the initiatives are what the IR thinks is good for the customer and not necessarily driven from the customers' perspective. Strategies and processes have to be scientifically

based. This needs a paradigm shift on research, development and training to evolve and sustain increasing asset utilisation and new technologies and systems that are world class. There is scope in increasing the asset utilisation in all the infrastructure elements: right of way (track), rolling stock (locomotives, coaches and wagons), and terminals. Given a railway system that has a natural advantage of scale, investments in research, development and training will yield long term returns, not only from use in $I R$, but also from global markets. To sustain the above, IR needs to focus on organizational restructuring.

\section{ACKNOWLEDGEMENTS:}

1. Dr. Jeppiaar, Chencellor, Sathyabama University, Chennai-119, Tamilnadu, India.

2. Dr. N Manoharan, Dean (PG studies \& Research), Sathyabama University, Chennai - 119, Tamilnadu, India.

\section{REFERENCES:}

[1] 2006, Planning Commission (2006). 'Towards Faster and More Inclusive Growth: An Approach to the 11th Five Year Plan, 'Government of India, New Delhi.

[2] 2001, NCAER (2001). 'The Indian Railways Report2001.' Expert Group on Indian Railways, National Council of Applied Economic Research, New Delhi.

[3] 2007, MOR (Various Years-d). 'Memorandum Explaining the Proposals for Adjustments in Freight Rates and Passenger Fares in the Railway Budget.' Ministry of Railways, Government of India, New Delhi.

[4] 2007, MOR (Various Years-a). 'Year Book,' Ministry of Railways, Government of India, New Delhi.

[5] 2007, MOR (2006-a). 'Data Book 2006-07,' Ministry of Railways, Government of India, New Delhi.

[6] 2003, Business Line (Nov 26, 2003). 'Freight, Passenger Fares May Be Spared in Rail Budget.'

[7] 2006, India Today (May 29, 2006). 'The Best \& Worst Ministers.

[8] 2006, Indian Express (April 2006). 'Sizing up the Railway Ministers, 'Express Survey on Railways.

[9] 2007, Speech of MR the Railway Budget for 2007-08, Part I \& II, Ministry of Railways, Government of India, New Delhi.

[10] 2008, Performance Budget of Railways, Ministry of Railways, Government of India, New Delhi. 